\title{
Job Insecurity in Private Education Sector Considering COVID-19 Pandemic: Bangladesh Panorama
}

\author{
Md. Ali Imran \\ Lecturer \\ Department of Business Administration \\ CCN University of Science \& Technology, Cumilla, Bangladesh \\ Ikbal Ahmed \\ Lecturer \\ Department of CSE \\ CCN University of Science \& Technology, Cumilla, Bangladesh
}

\begin{abstract}
Job insecurity is one of the vexed questions here in the COVID-19 pandemic situation. Private sector employees are agonizing mostly due to this problem. In the midst of July within three months of the crisis, about 13 percent of people have become unemployed in the country due to the Covid-19 pandemic. The educational institutions are closed in Bangladesh from 17 March 2020 due to this crisis. So the private education sector job holders are in a precarious situation in terms of their job security. In this study, we investigate the vacillation of job security for private education employees. For this purpose, we questioned 100 private education sector employees such as School, College and University to find out the actual scenarios. Most of the private educational institution depends on its own income from the student's tuition fees; hence the trouble to manage it for the deadlock condition and their employees are also in a financial dilemma. Though some of them are started online programs in the true picture, they will suffer as the ballgame advancing. Bangladesh's government announces thirty thousand core incentives to face economic hazards. The particular employees in this stratum are benefited from trivial brink. Some lay off strategy can save both the victimized party.
\end{abstract}

Keywords: Job Insecurity, Private Educational Sector, COVID-19, Unemployment.

\section{Introduction}

On January 8, 2020, a novel coronavirus was officially announced as the causative pathogen of coronavirus disease 2019 (COVID-19) by the Chinese Center for Disease Control and Prevention. The pandemic COVID-19 has spread all over the world. This virus can contaminate people easily. Due to this, countries have been closed down every activity and shopping for anything but necessity commodities. The COVID-19 outbreak is one of the worst global pandemics for decades. The International Labor Organization (ILO) predicted around 24.7 mil-lion jobs will be disappeared due to COVID-19. Like the other developed and developing counties, Bangladesh is also one of them who will be affected higher than anyone. The educational institutions in Bangladesh are closed from 18 March, 2020 to minimize probable health risk. That opens the risk of job insecurity in private education sector employees those institutions are depends on its own income.

According to Guy Ryder, director general of the ILO, the world is unanimously addressing the world economic crisis where the worst advancement can be averted and resolved through dynamic leadership.

The corona virus (COVID-19) crisis has resulted in an unprecedented labor market shock and unemployment crisis. Millions of jobs have been put at risk as a result of the unparalleled social distancing measures enforced across Bangladesh. About 13 percent people have become unemployed in the country due to Covid-19 pandemic, according to a survey of Bangladesh Institute of Development Studies (BIDS). In the field of private education sector the employees can be categorized in different layers such as kindergarten, primary school, high school, colleges, higher education employees and other sectors in private education. Most of the employees in these private education sectors are getting no salary or lesser percentage of salary for the current situation. Some of them are in a mental hazard of losing their jobs.

The COVID-19 pandemic, however, is a crisis of a completely different magnitude and one that will require a response of unprecedented scale. The COVID-19 pandemic has brought in a paradigm shift in the 
understanding of human rights jurisprudence. Like many other human rights, the right to private education sector job security is now continuously being rethought and renegotiated within the economic priorities. Education is the backbone of a nation and education sector employees are the support to this backbone. Without the support to this backbone we cannot go far as a nation. As we know 3.8\% of total employments in Bangladesh are from government services. A great number of congregate employments are from private sector. This is not different for education sector in Bangladesh. There are over 7,500 approved non-MPO (monthly payment order) educational institutions in the country with 2, 00,542 teachers and staff combined approximately. In the higher education sector there are 107 private universities in Bangladesh. There are private owned medical colleges. Thousands of employees are working there. Most of the employees are not treated properly how they should be treated as a respectful employee in this deadlock situation. Many of non- MPO employees are reported as they are not getting any salary from the outset of standstill conditions whereas many are at the risk of job sack. Some of employees get half and few are getting a portion of their stipulated salary.

There are number of private education sector employees conducting online classes. In higher education UGC (2018) provides logistic support to resume online classes. Many of the private education sector employees conducting their classes through Zoom, Google meet or using many other applications. Private universities, schools and colleges are perusing the online examination to minimize the session losses. They are using modern technologies and putting hard labor in this prospect. But most of them are not going smoothly in terms of their job security. According to study Bangladeshi educational sector employees are served lesser in compare to other countries in the world. The government and the concern authority should pay attention and impose extra care to these noble professionals otherwise the nation will suffer in the long run.

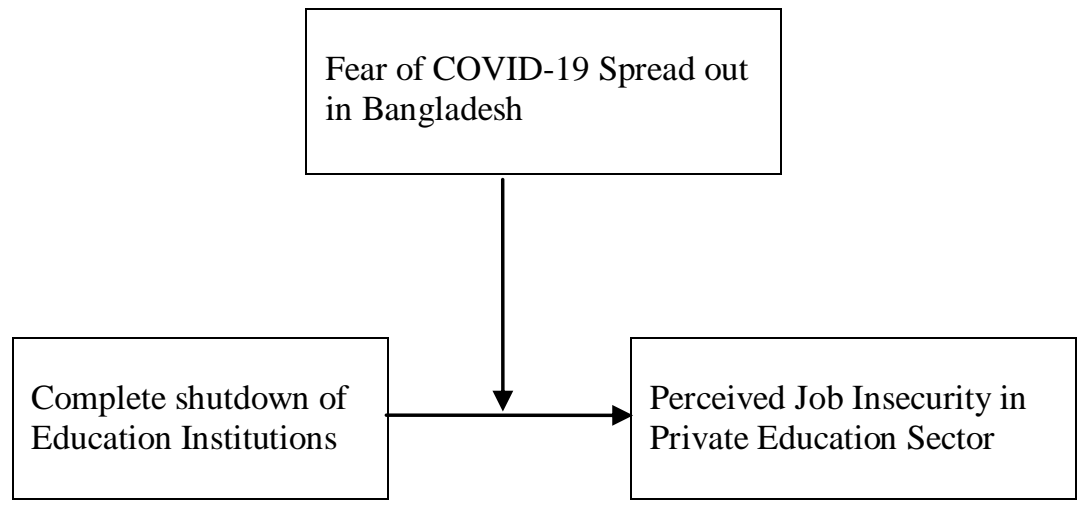

Figure1. The Moderation Model Hypothesized

\section{Objectives of the Research}

The primary objective of the study is to find out the impact of COVID-19 on private education job sector. The secondary objectives of this study are the following discussion: To find out the initiatives should take by government and different stakeholders in Bangladesh to protect the employees "lives and rights"; and to write down a few future strategies to minimize the impact of this kind of pandemic or emergencies in the future.

There has not been any job insecurity study relating to COVID 19 pandemic in private education sector in Bangladesh. As it is known almost all the studies conducted in Bangladesh are related to other economic sector employees. No one is paying heeds to these deprived employees but some are leading miserly and challenging life here in this pervasive world. Therefore, the study primarily aims at evaluating the job insecurity in the private education sector from the 'employee' perspective. The basic objectives regarding job insecurity in private education sector are:

- To analyze the present scenario of job security in the emergency due to COVID19 pandemic in private education precinct.

- To evaluate the employees job sustainability in the advancement of the pandemic.

- Determining the relationship between employee perception and actual scenario in this private education sector. 
- To explore the job satisfaction of private employees in terms of financial and socio- economic structure of Bangladesh.

- To suggest some policy measures for improving employees job security.

\section{Data Collection Strategy}

In this study two types of data are used to perceive the job insecurity in the private education sector employees due to emergencies like COVID 19 pandemic. We use both the primary and secondary data.

In terms of collecting the primary data we make a questionnaire having 20 questions to find out the sustainability and socio economic condition of the employee in private education sector. We reached them through the Google docs as the country was lockdown and also to maintain the social distancing. They eagerly participated and provided their important opinion to conduct this study.

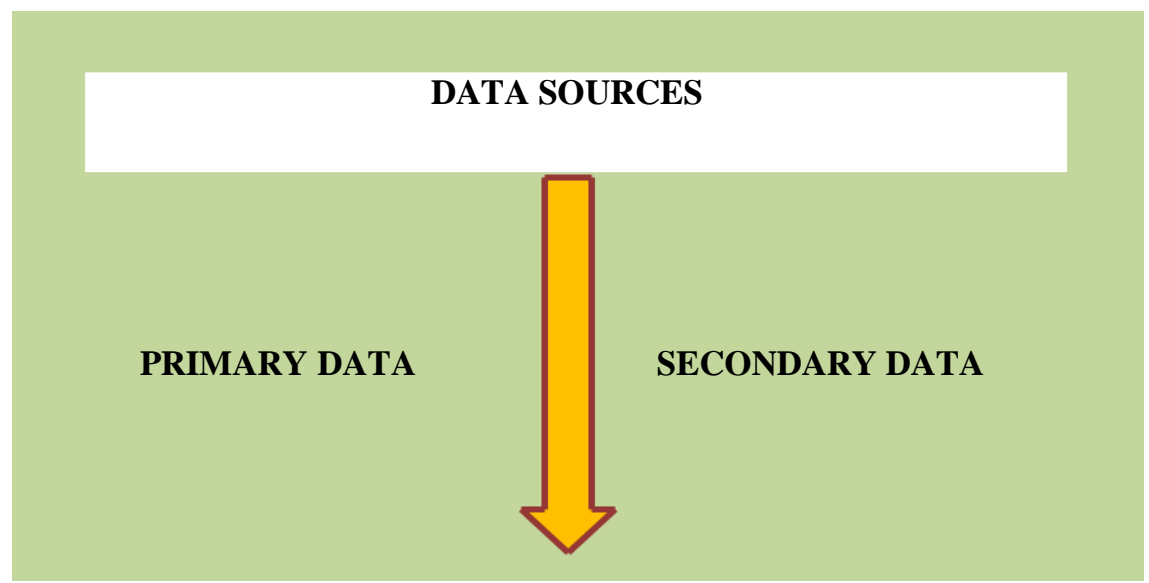

Figure 2. Research Data Sources

We use the five point likert scale method to construct the questionnaire. We investigate the situation constructing some physical question. To ascertain the actual scenario we discussed with the private education sector employees and faculty members. For this aspect we adopted proper physical distancing procedure, especially we conducted through the social networking platform like Facebook, messenger, twitter and whatsapp.

To understand the impact of COVID-19 on the private education job sector in Bangladesh, the secondary information also been used. The previous literature review, newspapers, and scholarly reports have been used to compile this study. For the data collection, online media has been searched regularly from February 2020 to august 2020 for collecting the stories relating to the COVID-19 effect on private education sector employees. The main reason for using the newspaper information is there is not enough information available in the similar research field, except the form of newspaper. Moreover, the newspaper information is supportive to develop the theoretical postulates. For the Western media outlets Google News searching strategy has been used. And, for the local newspapers i.e. Prothom Alo, Financial Express, Dhaka Tribune, Daily Star etc. have been regularly viewed. After the initial screening, the relevant stories have been stored as PDFs at the analytical software. For the article review the Google scholar is used to find out the relevant articles and citations.

\section{Literature Review}

Although the actual fact that the Covid-19 job insecurity episode and related confinement measures implemented by governments across the planet passed within the first two quarter of 2020, there's burgeoning research on this subject, as researcher have sought to use any possible data analysis and evidence to know better and mitigate the adverse consequences of the pandemic. Given the lag in collection and publication of official job market statistics and lack of clarity on the state of the unsecured employment, many voluntary targeted surveys have also been distributed.

Investigate on the labor economics literature, several new research studies have sought to supply a preliminary assessment of the impact of the Covid-19 crisis on jobs and workers. Baldwin and Weder di Mauro (2020) provide a guideline of the previous literature on the financial consequences of the pandemic. In a study of 
primary assessment employing a large-scale household survey Coibion, Gorodnichenko, and Weber (2020) highlight that job losses within US are significantly understated in new unemployment claims. The reason what by historic standards a large decline within the employment to population ratio has not been mirrored by the same increase within the percent. The authors attribute this discrepancy to the reason that speed of inactivity has risen, with newly non employed people are not actively seeking work.

Béland, Brodeur, and Wright (2020) build three indices using US data to research the short term impacts of Covid-19 on employment and wages investigating on the mirrors paper on EU job market during pandemic. They classify jobs in step with their exposure to disease, proximity to coworkers and also the capability to perform remote work. Their analysis confirms, exploiting state-level variation, that the pandemic has caused a negative short-term increase in unemployment and reduce within the labor participation rate and work period. The author's show that occupations that rely upon physical proximity to others are more affected, in contrast to occupations possibly be performed remotely. The US evidence warns that the general physical crisis will magnify marketplace inequalities, as men, younger workers, immigrants, the self-employed and fewer educated workers are more likely to be negatively littered with Covid-19.

Adams-Prassl, Boneva, Golin, and Rauh (2020) as leverage evidence from real time surveys from Germany, the united kingdom and therefore the US to point out that the employments impacts of Covid- 19 differ significantly across countries and employee characteristics, exacerbating EU jobs highly unsecured due to Covid-19 social distancing inequalities. Their investigation is predicted on identifying the share of tasks by occupation that may be done remotely, which is very predictive of job sack. They show that the negative consequences of the corona virus outbreak on current and expected job loss those with less secure work arrangements and therefore lower skilled. Workers on short time work schemes are marginally victimized by the pandemic, focusing the essentials of the institutional framework underpinning labor markets in numerous countries.

Mongey, Pilossoph, and Weinberg (2020) investigate the characteristics of workers in jobs likely to be initially laid low with broad social distancing and later by narrower policies tailored to jobs with low risk of disease transmission. The authors use online data to construct a measure of the likelihood that jobs may be performed from home and a measure of low physical proximity to others at work. They confirm that less educated workers, those with lower income and possession of assets relative to income and renters face higher vulnerability. The study further confirms a negative relationship between working from home jobs and declining employment, using March 2020 official labor pool data.

McGuinness, Redmond, and Delaney (2020) also face the difficulty which Irish workers can potentially work from home. They highlight how teleworking is critical not just for continued economic performance, but also assist control another spike in virus cases and alleviate child care pressures caused by school. The authors stated approximately $14 \%$ of employees in Ireland currently work from home in some formal capacity, mostly within the education, ICT and finance sectors, while this figure falls to $6 \%$ for 'essential' employees and couple of those within the accommodation and food service sectors. Results from their econometric model indicate that men, Irish nationals, older workers, full time employees and people in higher paid occupations have most probability of performing from home.

Baert, Lippens, Moens, Sterkens, and Weytjens (2020) focus on career outcomes and career aspirations due to COVID-19 crisis. Belgian employees reported that about 21\% fear for the job sack where $14 \%$ are at the risk of losing their job in recent times. Study ascertains that approximately $26 \%$ of migrants will face the COVID-19 wave in the economy as the risk of their promotion prospect. Emphasizing, the study shows that most of them will affected individually in terms of their job insecurity and further job placement.

Gasparro et al. (2020) presented the correlation among the Italian employees fear of covid-19 and its affects to their job department. The fear to the pandemic impacted to their mental health which directly affects their work environment. It causes the perceived job insecurity among the employees and they face some depressive symptoms. In their study they focus on the job insecurity due to covid-19 pandemic and the relationship with the mental stress of their job losing.

Finally, Sen, Antara, Sen, and Chowdhury (2020) they emphasizes on the apparel worker in Bangladesh who are in a deep sea losing their jobs at the very outset of the pandemic. The apparel workers are truly in the highest level of vulnerable position in Bangladesh. In normal condition they have some miserable life but situation get worsen and millions are losing their job due to the covid-19 pandemic crisis. In this study they showed that around $45.7 \%$ of order cancelled due to pandemic crisis. Reportedly $5.9 \%$ say all of their foreign order are cancelled which caused the situation worsen. 


\section{Underlying Theory}

\subsection{Past Research-Maslow's Hierarchy of Needs Theory}

Abraham Maslow introduced the hierarchy of needs theory in 1943. Though the theory proposed a sequential hierarchy of five basic needs which are all-pervasive (Shahrawat \& Shahrawat, 2017), at the heart of the theory there is an aspiration to build up an affective and empathetic working condition to motivate the employees to retain in Organizations.

This theory was based upon the premise that higher level needs are not important and are not manifested until lower-level needs are satisfied. The most basic needs of individuals are labeled as physiological needs and included such items as food, water, sex, sleep and other bodily needs (Martin \& Frost, 2011). The next most important level of needs is safety. This included items such as security and protection from physical and emotional harm in the work environment which must be without fear and enjoyable (Robbins \& Judge, 2007). The third level of needs is social needs. This level of need included affection, love and belongingness which can be dubbed as desire for social belonging (Martin \& Frost, 2011). The fourth level of needs is esteem needs. This level included self-respect, status, prestige and recognition emanated from effective and efficient leadership in the work environment (Martin \& Frost, 2011). The highest level of need is self-actualization. Self-actualization is the drive to become what one is capable of becoming and achieving their potential level of achievement in the career ladder (Robbins \& Judge, 2007). The needs represented by Maslow's hierarchy can be applied to the work environment as a way to motivate employees. In gist, pay and work hours can contribute to satisfying physiological needs. Safe working conditions, company, benefits and job security help fulfill safety needs.

Friendly supervision and professional associations relate to social needs. Job title and social recognition help fulfill esteem needs. Finally, a challenging job, opportunities for creativity and advancement in the organization can mean to fulfill self-actualization needs (Shahrawat \& Shahrawat, 2017). The challenge for organizations is to consider these employee needs as they implement work environmental practices (Martin \& Frost, 2011).

An underlying premise of the current study is a secured and healthy working condition that is central to motivating the employee to stay longer with an organization. Muslow's theory provides a robust theoretical basis for testing such a premise, along with an additional framework for testing whether quality education is affected by employee retention, which itself should be dependent on enjoyable working condition of the educational organization. Based on the theory, sound working condition in the private education institutes should positively influence faculty retention practices. Finally, enhanced retention practices should influence as a mediating variable to influence quality education as well as directly influence quality education itself.

If we cannot retain our teacher \& employees involved in private education sector we cannot hope for quality and skillful education from them. Day after tomorrow there must be flip flop condition which is not up to scratch in our private education systems. As higher percentages of students are involved in private education sector we cannot hope for scholarly generation in the education field without committing secured and skillful private sector employees. Talking with the private education sector employees physically we wants to discover that the government and the concerned authority are not taking any notable steps to minimize the outcome created in these emergencies. They want a unique job policy and financial structure from the government. The special scheme to fight emergencies like COVID 19 pandemic the government can initiate some special schemes. From owner side they want some mental and financial support and sustainable job policy that will be applicable in any hazards.

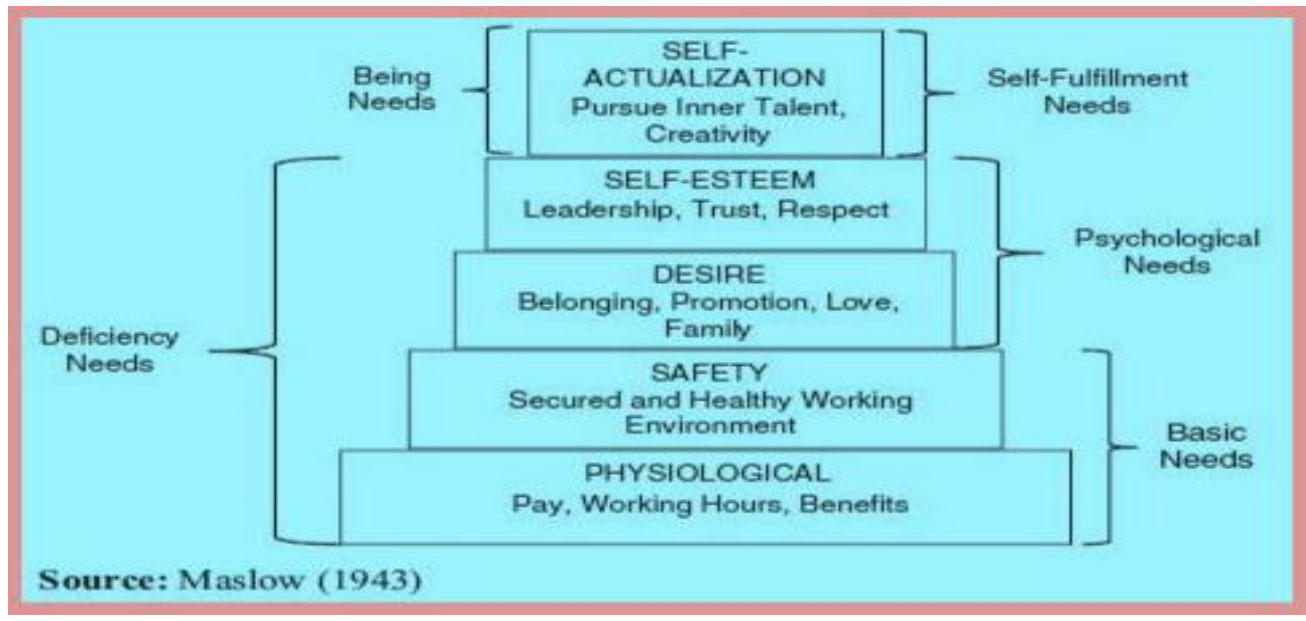

Figure 3. Maslow's Hierarchy of Need Theory 


\subsection{Job Insecurity in Different Layers of Private Education Sector}

In a recent study conducted by Bangladesh Bureau of Statistics (BBS) it is found that $76.1 \%$ of total employment is from private sector. Among them a notable number are working in the private education sector.

The educational institutions are closed for 6 months that means all the activities in most of the institution are closed. Though many school colleges $\&$ university started their distance learning through online classes but there are lots of challenges to make it successful. Specially most of the students \& teachers are not trained to the technology. The internet problem in the rural area makes it difficult. Most of the students do not have well equipped devices to make it happen whereas some have economical adversity.

In our recent study we noticed that only $25-30 \%$ private sector educational institutions are conducting their online classes others are in a standstill situation. Many kindergarten, school and colleges are totally stopped their activities due to pandemic situation. They cannot afford any salary to their employees for 6 months. In a report from renowned newspaper i.e Prothom Alo we came to know that many school and colleges employee are not getting salary from March from when the educational institutions are closed. They are in a threat to lose their job as well.

The higher education sectors like private universities are in a little better position rather than the primary school, high school and colleges. Most of the universities started their distance learning through online classes. Some are conducting online examinations through different technologies.

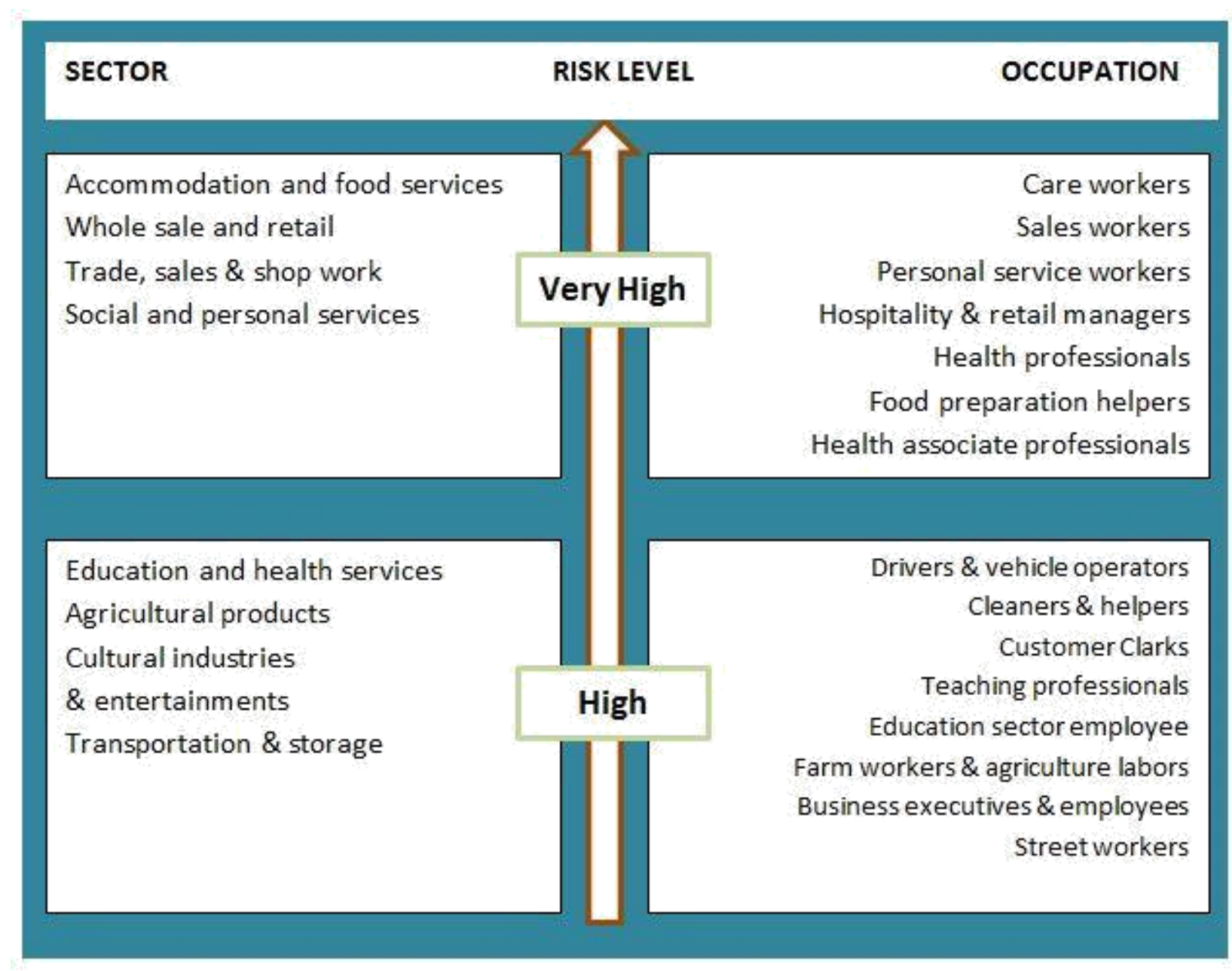

Figure 4. Job Risk Level in Private Sector Due to COVID-19

As the economy of the country are not in the fullest stream there also some adversities. Most of the universities are paying 50-60 percent of the total salary we found according to our face to face questionnaire. The admission \& tuition fee earnings are not satisfactory to be in content position as their financial structure designed 
with them. Many of them thinking to cut down the expenses through job sack in order to cope up with the situation which put the employee in an unsecured phenomenon.

From the above discussion and the graph presented in the above we come to know that some private sectors are in very high risk and some are in high risk in terms of their job security. Private education sector employees are in a high risk to their job sustainability (Cedefop, 2020).

\section{Data Analysis and Findings}

The employee's job place environment is reported in Figure-05 Data was collected from 100 employees. After collecting data, it is found that there is none who is strongly disagree or strongly agree. There were two questions about the environment. First question was on the employee's satisfaction with his job place environment and the other was on the standard facilities in his work place. In both questions, they hesitate about the telling their own institutions. The two figures show that a large number of employees remained neutral. It shows that most employees are somehow in pressure not to tell about the environment and standard facilities of their institutions. Although $38.1 \%$ employees are satisfied with the job environment, the same numbers of employees are not satisfied with the facilities they enjoy. It shows that the authority is unwilling to provide standard facilities for the employees. That's why, $28.6 \%$ employees are agreeing with the standard facilities.

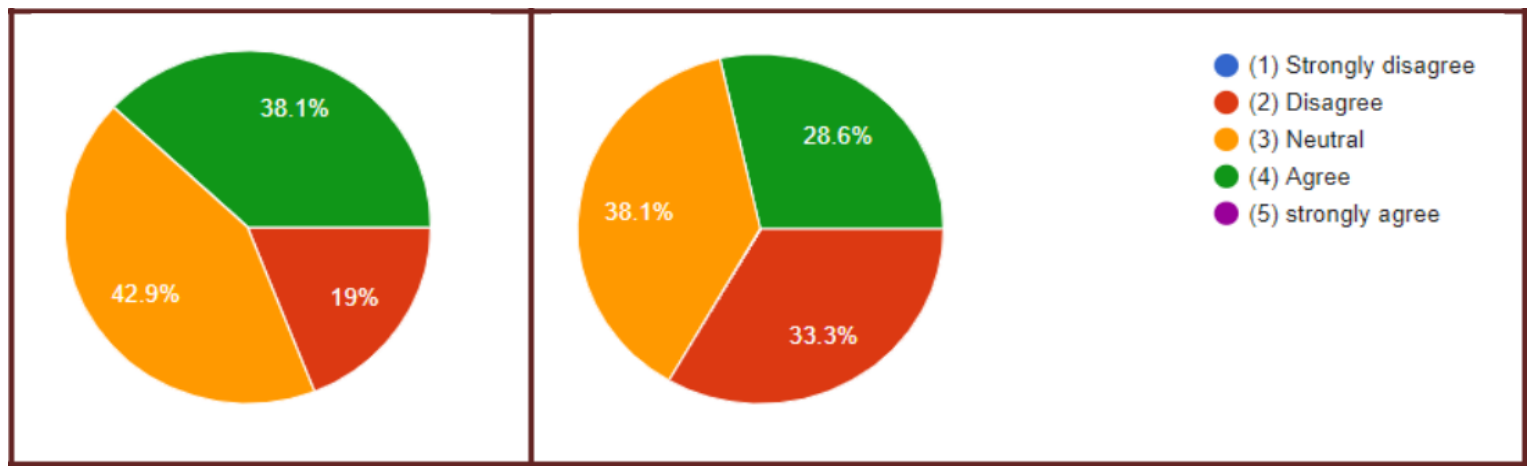

Figure 5. The percentage of the employees about own job place environment

Figure-06 shows the satisfaction about their salary. There are two charts, left-side chart shows about the salary structure and second shows whether their salary is given in time or not. About the salary structure 14.3\% employees are strongly disagree that there is salary structure but it is not satisfactory level. The highest rate is $42.9 \%$ employees are disagreed about these criteria. It is clear that the employees are not satisfied about their present salary structure.

In the right-side figure, the highest rate $33.3 \%$ employees are disagreed and $23.8 \%$ are strongly disagreeing about their salary in time. So, the employees who are serving in private education sector are not satisfied about their salary and also about their institution.

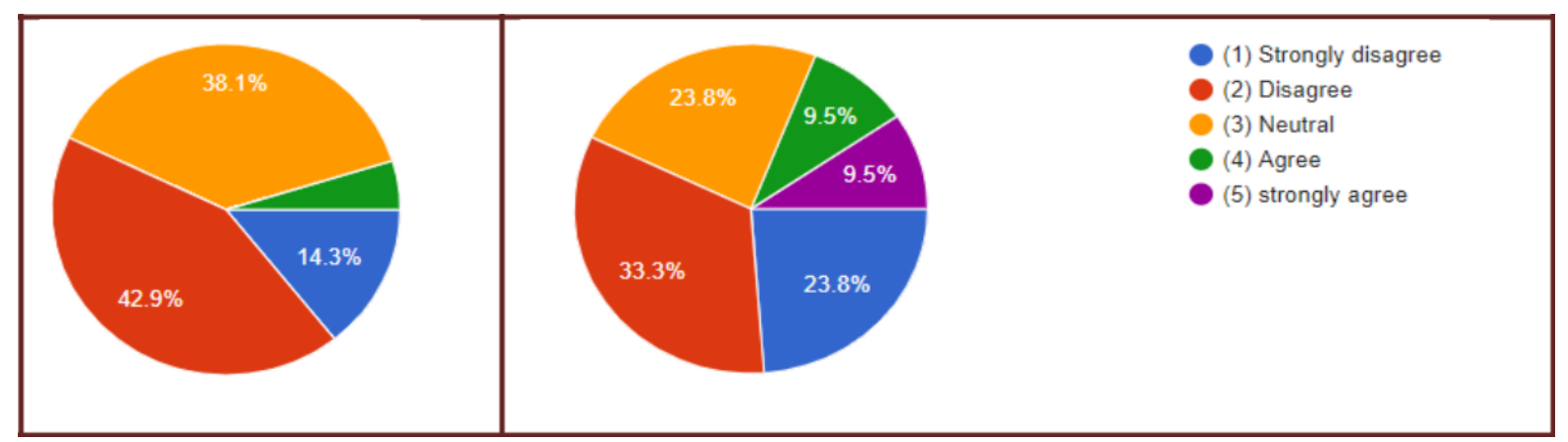

Figure 6. The ratio of number of the respondents about their salary structure 
Due to Covid-19 pandemic, many sectors are in the verge of destruction. Covid-19 has a great negative impact on education sector. Many institutions are facing financial crisis. They can't run their institutions smoothly. The Figure-07 in the left side shows that a good number of respondents are agreeing on the point that their institutions are facing challenges due to the pandemic. It is seen that $66.7 \%$ employees are agree on this point while only a negligible number i.e $4.7 \%$ employees are disagreed.

The figure-07 in the left side shows the percentage of the employee who are agree that challenges in his/her institution due to pandemic and also about the job sack. We note that we seem to have $66.7 \%$ employee are agree about that there are challenges in the institution and few numbers are disagree.

The figure in the right side shows that a large number of employees i.e. $47.5 \%$ employees have no idea whether they have a chance to be sacked or not. But $19 \%$ employees are agreed that they may be sacked. On the contrary, 9.5\% employees are strongly disagreed on this point. It shows that their institutions have vast resources and no problem to run. The situation may be reverse also. The authorities may be more humane.

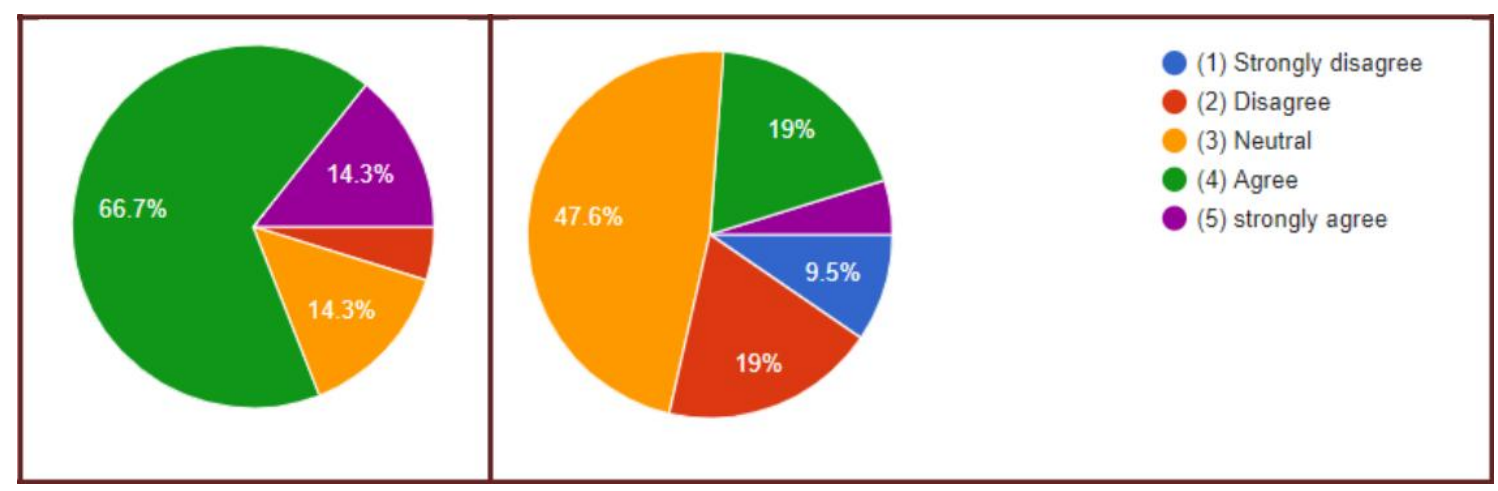

Figure 7. The ratio of the number of the respondents about the institutional policy

The governmental support for the private education sector from the perspective of employee is reported in Figure-08. In this pandemic situation, the employees feel the necessity of the support for the government for the private education sector and also for them. The left side figure shows that the highest percentage is $57.1 \%$ employees are agreed and $38.1 \%$ are strongly disagreeing about the finding of any support from the government. The right-side figure shows the similarity of the percentage of the employees who are agreeing about the necessity of the government support for the private educational institution.

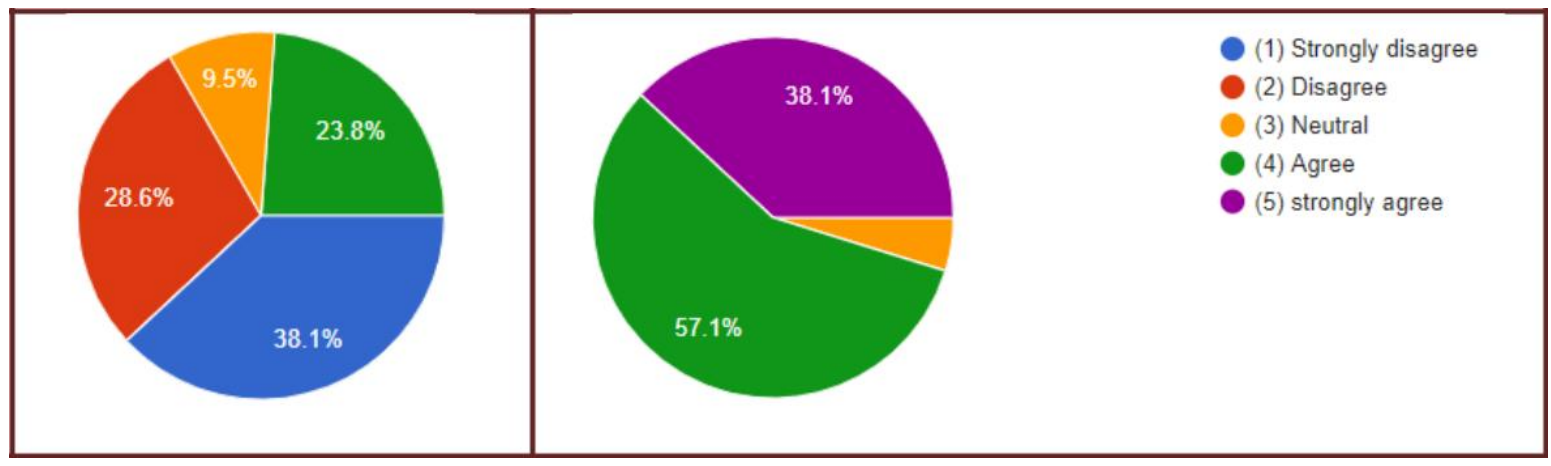

Figure 8. The ratio of the number of the respondents about the government support

\section{Result and Discussion}

Results show that employees at risk of losing their jobs showed higher levels of perceived stress and negative feelings and lower levels of positive feelings compared to employees not at risk of losing their jobs. Results also showed that $19.05 \%$ of the group at risk of job sack where $47.61 \%$ in the neutral position. It shows that most employees are somehow in pressure not to tell about their problems. As this study was carried out within the first five months of the pandemic panorama, results of the study reflect the immediate, short term reaction. However, our 
results need to be treated with caution as we are unaware of the long term impact of the economic crisis in Bangladesh and its potential impact on our sample.

Results showed no spillover effects of the negative consequences of job insecurity on employees working in proximity but not currently at risk of losing their job. This could be time-related as secondary effects of insecurity might need more time to develop. For example in the study of Lang et al. (2012) musculoskeletal problems of employees that survived a downsizing of staff were stronger relative to musculoskeletal sickness absences measured for an extended period covering two subsequent years after downsizing, suggesting that negative effects may be more pronounced later on.

The satisfactory level in salary structure here in pandemic circumstances showed higher percentages of discontentment which is $42.9 \%$ in true picture. $33.3 \%$ are emphasizes on they are not getting their salary in time and they are getting the partial amount in this emergency period. In the contrary they should get the extra care in this crisis moment. But the $42.9 \%$ strongly disagreed on the point of festival bonuses and $33.4 \%$ on the side of getting no incentives from the authority. A great percentage of respondents (nearly 43\%) opine that there are pecuniary uncertainties if the quadrangle advances. 66.7 percentages urges on academic and institutional challenges due to COVID 19 pandemic. An inflated number of employees (57.1\%) longing for the structured financial rules and regulation from the government side whereas $38.1 \%$ are strongly agreed on this point. Approximately $58 \%$ of employees want a unique job policy for the private education division employees and $28.6 \%$ strongly agreed on this point to enhance their job security.

From the above discussion and result analysis we can urge that the private education sector artisan wants a healthy turnover in their job environment focusing on emergencies like COVID 19 pandemic. They crave for a secured job sector where the sustainability will revamp the quality education. As they are the builder of a nation the government and owners can work hand in hand to improve policy and job structure to protect their right. By ensuring so we can build an intellectual nation who will serve the nation and help to procure a developed country by 2041.

\section{Recommendation}

COVID 19 pandemic teach us some lessons that we should look forward for sustainable economic structure. The government and the concern authority should prepare for the emergency situation like COVID 19 pandemic. This disaster shocked the whole economy. The World Bank estimates that the GDP growth will fall to 1.6\% in 2019-20 fiscal years where the GDP growth in last year was $8.15 \%$ according to BBS. The private education sector is not out of this problem. For the corresponding pandemic situation the job security in this sector are at a risk. Some recommendations to protect these employees benefit are mentioned below:

- Ameliorate the communication and transparency:

Communication is very crucial following the pandemic, in order to reduce employees' uncertainty and their level of stress. In this context, a communication plan should be developed in order to provide clear information to employees about what will happen after COVID-19, what are the main actions that will be taken to resume organizational operations, and the potential impact of these actions on employees work. Providing clear and transparent information about the organization's future plans may reduce the fear of the unknown and job insecurity.

\section{- Prevention of stigma}

Stigmatization can be minimized by providing accurate and timely COVID-19 information (Bai \& Ng, 2004) and training (Brooks et al., 2020) to employees during and after the pandemic outbreak. Furthermore, organizations should construct workplace policies that avail stigma prevention providing true information. Social connection through online meeting and cooperation among the employees maintaining the technologies can fulfill these criteria.

\section{- Online Training \& online classes}

"Training on Conducting Online Classes" and "Outcome Based Educations (OBE)" can help both the employees and students to fight against the adversities. Online training conducted by the UGC (2018) can help the employees in earning confidence and thinking of unknown future. The students will be encouraged by these kinds of activities to normalize in online classes and the whole picture of education system. They can minimize the job insecurity in private education sector adopting quality online classes. I think interactive online classes are the major solution to this quandary. 


\section{- Social support}

Social support can enhance the mental condition of the employee which directly affects the education environment. If they get the trust and believe from their surroundings it will enhance the quality education through distance learning. The employee will feel secured as per their job concern.

\section{- Management of teleworking and prevention of social isolation}

In order to prevent the negative outcomes of teleworking on employees' mental health during COVID-19, organizations should develop proper strategies to support employees during organizational changes. The study of Greer and Payne (2014) put forward some strategies identified by teleworkers, that may help to overcome the challenges of teleworking. Teleworking like conducting online classes and taking examination through modern technologies can normalize the scenarios in financial aspect which is the main concern for the owner in current situation. The employees can perform teleworking which will normalize this division and prevent social isolation problem.

\section{- Providing some special incentives and technological support}

In this pandemic the job market become unstable in the whole world especially in the private sector. Though the different countries adopting different financial schemes. The private education sectors are overlooked in Bangladesh. The margins of financial support to this sector are very little. The government and the instinctive authority can adopt some special incentives for the employees. The technological support like free devices and internet for both the employee and students can lay out the problem in this section.

\section{- Constructing unique job policy and financial structure}

The private education sector now facing the problem is job instability due to financial crisis. We know that all of the private educational institution depends on its own earnings. These types of crisis are never happened before and they are not use to it how to handle this problem. Though some of them is going smoothly where most of them facing vice-versa. The owner and the concern authority should come forward to protect the employees' right implementing some special financial structure and job policy to fight against the emergencies.

\section{- The owners can diversify their earnings}

In this current unsecured world the ultimate problem is the financial cataclysm faced by the private sector. The private education department cannot come out from this setback. Most of the employees in this precinct are getting no salary or partial salary. This make these employees unsecured and they are thinking of job sack where worst situation come by in near future. It makes them to re- think and fear to uncertainty. The owner can invest in diversified business and expand their wings. They should not depend only to their student's tuition fees. This diversification will help them to confront against adversities like COVID 19 pandemic in future.

\section{Conclusion}

The COVID-19 pandemic has resulted in unprecedented economic ramifications and job loss. Due to the rapidlychanging nature of the pandemic, those currently employed may be experiencing heightened job insecurity and financial concern and the present finding show that greater job insecurity due to COVID-19 among those currently employed in private education sector employees. In this article, we have argued that the Covid-19 pandemic can be considered a career shock that will have a major impact on people's work and careers in private education tract.

As mentioned earlier, the concept of private higher education in Bangladesh is relatively a new phenomenon in the education sector which was entirely within the public domain before the 1990s. As a nascent sector, it has been suffering from myriads of management problems. particularly, working conditions prevailed in these universities are not up to that level which is pleasant for the faculty members due to many of ill managerial policies (Joarder \& Sharif, 2011). The results of this study reveal that this factor is considerably important to maintain a steady faulty retention policy and job certainty in the entire private education section. There have been several studies report that turnover intentions of the faculty member in these private universities, non- MPOs school and colleges and private owned educational institutions in Bangladesh are significantly high which is responsible for reducing quality education. In this respect, the present study has offered important evidence that faculty working condition and job security in the private education in developing context can have significant influence on employee retention as well as on quality education in the private education belt in Bangladesh. 


\section{References}

Adams-Prassl, A., Boneva, T., Golin, M., \& Rauh, C. (2020). Inequality in the impact of the coronavirus shock: Evidence from real time surveys.

Brooks, S. K., Webster, R. K., Smith, L. E., Woodland, L., Wessely, S., Greenberg, N., \& Rubin, G. J. (2020). The psychological impact of quarantine and how to reduce it: rapid review of the evidence. The Lancet.

Bai, J., \& Ng, S. (2004). A PANIC attack on unit roots and cointegration. Econometrica, 72(4), 1127-1177.

Baert, S., Lippens, L., Moens, E., Sterkens, P., \& Weytjens, J. (2020). How do we think the COVID-19 crisis will affect our careers (if any remain)?.

Baldwin, R., \& Weder di Mauro, B. (2020). Economics in the Time of COVID-19.

Béland, L. P., Brodeur, A., \& Wright, T. (2020). The short-term economic consequences of Covid-19: exposure to disease, remote work and government response.

Coibion, O., Gorodnichenko, Y., \& Weber, M. (2020). Labor markets during the covid-19 crisis: A preliminary view (No. w27017). National Bureau of Economic Research.

Cedefop. (2018). Insights into skill shortages and skill mismatch: Learning from Cedefop's European skills and jobs survey.

Gasparro, R., Scandurra, C., Maldonato, N. M., Dolce, P., Bochicchio, V., Valletta, A., ... \& Marenzi, G. (2020). Perceived Job Insecurity and Depressive Symptoms among Italian Dentists: The Moderating Role of Fear of COVID-19. International Journal of Environmental Research and Public Health, 17(15), 5338.

Greer, T. W., \& Payne, S. C. (2014). Overcoming telework challenges: Outcomes of successful telework strategies. The Psychologist-Manager Journal, 17(2), 87.

Joarder, M. H., \& Sharif, M. Y. (2011). Faculty turnover in private universities in Bangladesh: the tripartite investigation. Int J Soc Sci Econ Art, 1, 118-123.

Mongey, S., Pilossoph, L., \& Weinberg, A. (2020). Which workers bear the burden of social distancing policies? (No. w27085). National Bureau of Economic Research.

McGuinness, S., Redmond, P., \& Delaney, J. (2020). Minimum wage non-compliance. Applied Economics Letters, $1-4$.

Martin, J., \& Frost, P. (2011). The organizational culture war games. Sociology of organizations: Structures and relationships, 315 .

Robbins, S. P., \& Judge, T. A. (2007). Organization behaviour. Translated by Benyamin Molan). Indeks.

Shahrawat, A., \& Shahrawat, R. (2017). Application of Maslow's hierarchy of needs in a historical context: Case studies of four prominent figures. Psychology, 8(07), 939.

Sen, S., Antara, N., Sen, S., \& Chowdhury, S. (2020). The apparel workers are in the highest vulnerability due to COVID-19: a study on the Bangladesh Apparel Industry. Sen S, Antara N, Sen S, Chowdhury S. The apparel workers are in the highest vulnerability due to COVID-19: a study on the Bangladesh Apparel Industry. Asia Pacific J Multidiscip Res, 8(3).

UGC. (2018). Annual Report, University Grand Commission, Dhaka.

\section{Copyrights}

Copyright for this article is retained by the author(s), with first publication rights granted to the journal. This is an open-access article distributed under the terms and conditions of the Creative Commons Attribution license (http://creativecommons.org/licenses/by/4.0/). 